Сергій Костів, Національний університет оборони України імені Івана Черняховського ORCID ID 0000-0002-9595-7803

\title{
ЕМОЦІЙНО-ВОЛЬОВА СТІЙКІСТЬ МАЙБУТНІХ ВІЙСЬКОВИХ ФАХІВЦІВ
}

У дослідженні теоретично обтрунтовано емоційно-вольову стійкість військових фахівиів, проведено ї̈ науковий аналіз, узагальнено та систематизовано інформацію з означеної проблеми, отриману з наукових і літературних джерел. Використано метод прогнозування для обтрунтування змісту емочійно-вольової стійкості та ї̈ розвитку в майбутніх професіоналів військового управління. Наукова новизна полягає в тому, щуо вперше обтрунтовано зміст їх емочійно-вольової стійкості. Перевірка розробленої моделі змісту емоційно-вольової стійкості майбутніх професіоналів військового управління в навчальному прочесі сприятиме перспективі подальщих наукових досліджень.

Ключові слова: емоційно-вольова стійкість; психічна стійкість; стрес-фактори; екстремальні умови; психічні стани; професійна діяльність військовослужбовия.

Постановка проблеми. Ведення сучасних бойових дій вимагає від військового фахівця психічної стійкості, упевненості у своїх діях і фізичної витривалості. Особливого значення набуває проблема його емоційновольової стійкості, що передбачає швидкість дій та адекватну поведінку в різноманітних складних і суперечливих ситуаціях, наприклад, у зоні АТО. Нині більшість військових фахівців виконують завдання, пов'язані 3 реальними бойовими ситуаціями. У цих умовах недостатній розвиток їх емоційно-вольової стійкості, що супроводжуються суттєвими психоемоційними навантаженнями, призводить до помилкових рішень, а у крайніх випадках - паніки, неадекватної реалізації завдань чи відмови від їх виконання. Крім того ця діяльність супроводжується обгрунтованим ризиком для їх життя та здоров’я.

Тривале здійснення своїх службових обов'язків у напруженій обстановці, наприклад, зоні АТО, веде до дезадаптації, зниження стійкості організму, нервово-психічних перенапружень, результатом чого $\epsilon$ розвиток стійких негативних психічних станів військовослужбовців. Проблема психічних станів $є$ однією з маловивчених і складних у психологічній науці, особливо в іiї прикладних розділах, пов'язаних із професійною діяльністю в екстремальних умовах. Зазначене зумовлює необхідність дослідження анонсованої проблеми та розгляду особливостей впливу емоційно-вольової стійкості на поведінку військових фахівців в екстремальних ситуаціях.

Аналіз останніх досліджень і публікацій. Дослідженням актуальних проблем визначення та формування професійних характеристик фахівця в умовах впливу екстремальних ситуацій займалися В. Андрусюк, В. Вареник, Ф. Думко, В. Свдокімов, Ю. Ірхін, Л. Казміренко, Л. Кітаєв-Смик, Я. Когут, М. Корольчук, В. Крайнюк, В. Маріщук, В. Розов та ін. Феномен емоційно- 
вольової стійкості був об'єктом наукових пошуків Н. Бабич, В. Власова, Р. Гасанової, Л. Заварзіної, П. Зільбермана, С. Кручиніна, О. Циганко та ін. Ці наукові напрацювання $є$ основою для дослідження емоційно-вольової стійкості - важливої психологічної характеристики представників екстремальних видів професій (військовослужбовців, рятівників, пожежних, співробітників правоохоронних органів тощо) та іiі впливу на поведінку фахівця в умовах довготривалої дії стресогенних чинників.

Головні завдання підготовки Збройних Сил України: логічно побудована схема, де визначено основний порядок та способи виконання завдань за призначенням, прийняття невідкладних заходів для відновлення процесу планомірного нарощування боєздатності військ (сил), підтримка в постійній готовності для відбиття воєнної агресії. Сучасні погляди військових фахівців на ведення бойових дій вимагають від них психічної стійкості, упевненості у своїх діях. Розвиток професійно важливих якостей офіцерів досліджувалося в роботах В. Ройляна, Б. Бахрєєва. Вивченням стресових ситуацій та адаптації до них займалися науковці (І. Волков, Ф. Горбов, Р. Лазарус, М. Левітов, О. Леонтьєв, Б. Ломов, О. Лурія, В. Мерлін, Н. Наєнко, О. Овчіннікова, А. Петровський, В. Суворова). Дії військовослужбовців у напруженій ситуації розкрито в роботах М. Дяченка, В. Дяченко.

Метою даного дослідження є обгрунтування змісту емоційно-вольової стійкості майбутніх професіоналів військового управління та на основі отриманих результатів дати визначення емоційно-вольовій стійкості майбутніх професіоналів військового управління.

Методи дослідження: комплексний науковий аналіз, узагальнення та систематизація інформації, отриманої $з$ наукових і літературних джерел, метод прогнозування для обгрунтування змісту емоційно-вольової стійкості майбутніх професіоналів військового управління.

Виклад основного матеріалу. Емоційно-вольова стійкість може розглядатися як один із важливих показників психологічної підготовленості військових фахівців до професійної діяльності. Як зазначає $Є$. Потапчук, емоційно-вольова стійкість - здатність протистояти реальній небезпеці, виявляти психічну витривалість і стійкість, вольовими зусиллями долати негативні почуття та психічні стани - виробляється у військовослужбовців у процесі психологічної підготовки [7]. Основна робота з іï формування має проводитися під керівництвом компетентного в цих питаннях офіцера чи психолога в ході професійно-психологічної підготовки. Звісно, це не виключає можливості саморозвитку та вдосконалення емоційно-вольових якостей військових фахівців у вільний від служби час.

Слід зазначити, що реалізація бойових функцій у професійній діяльності потребує високого професіоналізму, постійного самовдосконалення та саморозвитку військовослужбовця. Визначаючи сутність поняття професійного саморозвитку, ми спиралися на результати дослідження О. Петрикей [5], яка його розглядає як процес оволодіння новими професійно важливими знаннями, уміннями та навичками. Його 
рушійною силою виступає потреба в особистісному та професійному самовдосконаленні, творчій самореалізації, досягненні професіоналізму у своїй справі.

Як відомо, діяльність військових фахівців та їх поведінка зумовлена комплексом пізнавальних, емоційних і вольових процесів, цілеспрямованістю та наявною мотивацією. Зазначені феномени тісно взаємопов'язані та здійснюють вплив на їх успішну професійну діяльність, що в екстремальних умовах вирізняється 3-поміж інших видів діяльності високим рівнем відповідальності, психічної напруженості, емоційно-вольової стійкості й вимагає оптимальних, адекватних дій від особового складу підрозділів і частин. Ефективно працювати в зазначених умовах здатні психічно готові до такої діяльності військові фахівці. Однією 3 важливих складових цієї готовності $\epsilon$ емоційно-вольова стійкість, наявність якої сприятиме долати психічні напруження та регулювати власну поведінку у процесі виконання завдань в екстремальних умовах. Ці умови діяльності висувають підвищені вимоги до психічних i фізичних можливостей військового фахівця, наприклад, виконання бойових завдань у зоні АТО.

Так, О. Косолапов зазначає, що екстремальні умови $\epsilon$ певним сполученням, сукупністю різноманітних зовнішніх i внутрішніх стресчинників, що призводять до виникнення негативних психічних станів [4]. Отже, стрес-чинники - це такі психічні чинники, що негативно впливають на психіку військовослужбовця та дезорганізують його поведінку й бойову діяльність в екстремальних умовах.

Відомо, що їх поведінка в екстремальних умовах є реакцією-відповіддю організму на вплив стрес-чинників екстремальної ситуації, що проявляється в різних формах. При цьому поведінку та вчинки визначають особливості взаємодії властивостей, якостей i психічних станів, що виникають у конкретній нестандартній обстановці. Раціональність поведінки в умовах впливу стрес-чинників безпосередньо залежить від реакцій організму військового фахівця на екстремальні умови діяльності, які можуть бути досить різними. Проте для подолання негативних змін, що виникають під дією збудників, найоптимальнішими $\epsilon$ адекватні форми реакції, які $\epsilon$ передумовою раціональної поведінки фахівця в цих умовах. Вони мають спрямовуватися на ліквідацію або мінімізацію впливу екстремальних умов.

Отже, на думку науковців, адекватна реакція супроводжується підвищенням ролі вольових якостей фахівців, посиленням емоційного компонента, що бере участь у формуванні реакції-відповіді [8, 92-94]. Проте, як зазначає В. Розов, під впливом стресогенних чинників спостерігається велика вірогідність виникнення неадекватних (дезадаптивних) реакцій, що проявляються в агресивній чи аутоагресивній поведінці $[9,152]$. Також треба враховувати, що реакції, які виникають при зіткненні зі стрес-чинниками, особливо в АТО, за силою та характером багато в чому залежать від збудника. Серед зазначених стрес-чинників виділяють такі: новизна обстановки й невизначеність ситуації, які навіть за відсутності 
безпосередньої загрози для життя можуть викликати зміни у вольовій активності, протікання процесів сприйняття, мислення й пам'яті; обмежений простір, під впливом якого у фахівців спостерігається зосередженість на власних суб' єктивних відчуттях, що призводить до неадекватної поведінки та значного зниження результатів діяльності. Вище зазначене доводить, що емоційно-вольова стійкість є однією 3 основних складових у підготовці військового фахівця.

У наукових дослідженнях, присвячених емоційній стійкості, спостерігається велике різноманіття визначень і тлумачень цього поняття. Воно розглядається як співвідношення двох понять психології - «емоції» та «воля». Тому таку властивість частіше називають не просто емоційною стійкістю, а емоційно-вольовою стійкістю. Так, на думку науковців, під емоційною стійкістю доцільно розуміти складну динамічну інтегративну властивість особистості, що забезпечує високу продуктивність та ефективність діяльності й поведінки у складних емоційно напружених умовах [6]. Обгрунтовано іiі вважають однією з найважливіших і необхідних для збереження психічного здоров'я та профілактики емоційного вигорання якостей фахівців екстремальних видів професій. Поняття «емоційна стійкість» щодо військовослужбовців позначає синтез їх властивостей i якостей як суб'єкта професійної діяльності, що дає змогу впевнено й самостійно в різних емоційних умовах реалізовувати свої посадові функції.

У структуру емоційної стійкості як професійно важливої якості менеджерів входить п’ять підструктур: психофізіологічна, що є субстратом психічної діяльності (урівноваженість, рухливість нервових процесів тощо), емоційно-вольова (саморегуляція емоційних станів, емоційна лабільність, адекватність прояву емоцій та ін.), адаптивна (особистісний адаптаційний потенціал, нервово-психічна стійкість тощо), когнітивно-рефлексивна (самопізнання, самоусвідомлення), соціально-перцептивна (проникливість, емпатійність, ідентифікованість тощо). Емоційна стійкість, як припускають дослідники, змінюється під впливом пристосування людини до екстремальних умов, проте успішність адаптації залежить від низки стійких особистісних характеристик, зокрема, характеристик емоційності у структурі особистості, мотиваційних i вольових характеристик, стильових рис пізнавальної діяльності, пов’ язаних з емоційністю [6].

Її основу складає емоційно-вольова стійкість, що означає швидке орієнтування в умовах постійних змін обставин діяльності, знаходження оптимального рішення у складних нестандартних ситуаціях і збереження при цьому витримки й самоконтролю.

У наукових і літературних джерелах воля розуміється як психічний процес свідомої та цілеспрямованої регуляції військовослужбовцем своєї діяльності й поведінки $з$ метою досягнення поставлених цілей, а емоції особливий клас психічних станів, що відображають свідоме ставлення військовослужбовця до навколишнього середовища i до своєї військовопрофесійної діяльності. Крім того ми виділили основні прояви емоційної 
стійкості, а саме: настрій, пристрасть, переляк, боязнь, страх, афект, афективний страх, стрес, фрустрація та паніка, які мають властивість проявлятися в екстремальних ситуаціях.

У своїй науковій праці Г. Дзвоник підкреслила, що у словникудовіднику практикуючого психолога емоційно-вольова стійкість визначається як здатність психіки зберігати високу функціональну активність в умовах дії стресу, фрустрації як унаслідок пристосування до них, так і як результат високого рівня розвиненості емоційно-вольової саморегуляції [1, 25]. 3 наведеного вище, дане визначення щодо військовослужбовців можна трактувати як комплексну практичну властивість їх психіки, що проявляється в ㄲï стійкому функціональному стані під впливом стрес-чинників несприятливих обставин функціонування психіки. Дійсно, якщо у професійній діяльності військовослужбовців для досягнення мети виникають перешкоди, то однієї професійної підготовки стає недостатньою і вони використовують волю як психічну якість, а емоції як клас психічного стану.

Дійсно, як зазначає С. В. Зінченко, особистісна готовність майбутніх фахівців до діяльності в екстремальних умовах є емоційно-інтелектуальною, вольовою, мотиваційною, що містить зацікавлене ставлення до діяльності, почуття відповідальності, упевненість в успіху, потребу виконання поставлених завдань на високому професійному рівні, мобілізацію сил, подолання непевності тощо [2, 50-52].

Слід зазначити, що В. В. Ягупов визначив основні показники професіоналізму військового фахівця, які дають йому можливість успішно діяти в екстремальних умовах, а саме:

- суб'єктна компетентність як військовослужбовця i представника військової організації держави, що проявляється у сприйнятті, з одного боку, ним самого себе як військового фахівця, його практичному мисленні як військового професіонала, а 3 іншого - сприйняття його соціумом i військовим середовищем як військового професіонала;

- військово-професійна компетентність як представника конкретного виду i роду військ, наприклад, Сухопутних військ, Повітряних сил, Військово-морських сил Збройних Сил України;

- спеціальна чи фахова компетентність як конкретного військового фахівця, наприклад, командира, інженера, постачальника, які теж мають різні варіації прояву емоційно-вольової стійкості залежно від конкретного виду й роду військ;

- розвиненість особистісних і військово-професійних якостей та властивостей як фахівця екстремального виду діяльності, серед яких провідним є психічна стійкість до екстремальних умов дій;

- чітке усвідомлення професійно важливих цілей службової діяльності як суб'єкта військово-професійної діяльності та їх сприйняття як орієнтира дій; 
- володіння найсучаснішими, зокрема інформаційними технологіями, методиками й засобами вирішення службових компетенцій введення бойових дій;

- низький рівень залежності у процесі реалізації службових компетенцій від зовнішніх чинників, тобто професійна суб'єктність, що проявляється в автономності у процесі реалізації службових компетенцій;

- успішність, продуктивність та ефективність військово-професійної діяльності як актуалізації військово-професійної компетентності [10, 304305]. Їх творче врахування в конкретних обставинах екстремальних умов діяльності допоможе змістовно наситити емоційно-вольову стійкість військових фахівців загалом та офіцерів зокрема.

Необхідно підкреслити, що емоційно-вольова стійкість фахівців військового управління оперативно-тактичної ланки управління - це їх цілісна характеристика як військових фахівців та управлінців середньої ланки управління, що характеризує готовність і здатність протистояти стресогенному впливу у складних для функціонування психіки ситуаціях, i містить у собі практичну здатність витримувати надзвичайне збудження та емоційне напруження під впливом несприятливих стресорів, а також комплексну здатність зберігати без перешкод для цілеспрямованої управлінської діяльності високий рівень активності.

Підсумовуючи вищезазначене, дамо визначення емоційно-вольової стійкості майбутніх фахівців військового управління оперативно-тактичної ланки управління. Це цілісна характеристика психічної складової їх цілеспрямованої управлінської діяльності в повсякденних та, особливо, екстремальних умовах, готовність протистояти стресогенному впливу стресчинників несприятливих ситуацій військово-професійної діяльності, що містить у собі системну практичну здатність витримувати надзвичайні збудження та емоційні напруження під впливом стресорів військової служби, зокрема стрес-чинників бойової обстановки, а також комплексна практична здатність зберігати без перешкод для управлінської діяльності високий рівень військово-професійної й управлінської активності.

Вона забезпечує процес їх свідомої управлінської діяльності, що спрямована на досягнення поставленої мети при подоланні труднощів військово-професійної діяльності, які виникають як у повсякденних, так і екстремальних ситуаціях у процесі реалізації посадових компетенцій. Емоційно-вольова стійкість фахівців військового управління оперативнотактичної ланки управління - це практична здатність їх психіки зберігати високу функціональну активність управлінського спрямування в умовах дії стрес-чинників військової служби, особливо в бойових умовах функціонування військової організації держави, протистояти фрустрації - як результат пристосування до них, так і результат високого рівня розвиненості емоційно-вольової саморегуляції.

Таким чином, емоційна стійкість офіцерів - це необхідна психологічна умова для формування власної індивідуальності як суб'єкта військового 
управління та саморозвитку як військового професіонала. Вона забезпечує сукупність адаптаційних процесів, інтегрованість у розумінні збереження рівноправності основних функцій управління як управлінця у військовій сфері, стабільності їх реалізації, особливо під впливом стрес-чинників військової діяльності. Ї̈ї основний зміст складають стабільність, урівноваженість, емоційна лабільність, адекватність прояву емоцій та опірність психіки фахівців військового управління, інтегральним проявом яких є саморегуляція емоційних станів.

Емоційну стійкість слід розглядати як виваженість, рівновагу стабільності та змінності суб'єкта військового управління. Стабільність проявляється в головних професійних принципах і цілях, домінуючих мотивах, стратегіях поведінки, реагування в типових та, особливо, у бойових ситуаціях. Змінність проявляється в динаміці мотивів, появі нових способів поведінки, діяльності, виробленні нових форм реагування на типові та нестандартні ситуації управлінської діяльності. При такому розгляді в основі емоційної стійкості офіцерів лежить єдність стабільності й динамічності функціонування психіки, які $\epsilon$ доповненням один одного. Стабільність виконання не обов'язково передбачає стабільність структури функцій, найімовірніше, це характеристика достатньої гнучкості психіки офіцера в різних умовах управлінської діяльності. У стабільність психіки входить стабільність ㄲï функціонування, надійність офіцера в управлінській діяльності.

Урівноваженість - це здатність офіцера оперативно-тактичної ланки управління виважувати рівень напруженості управлінської діяльності 3 ресурсами своєї психіки та організму. Рівень напруженості не завжди зумовлений стресами й зовнішніми обставинами управлінської діяльності, а й суб'єктивною інтерпретацією та оцінкою цих обставин. Урівноваженість проявляється у практичній здатності мінімізувати негативний вплив суб'єктивної складової у виникненні напруженості в управлінській діяльності, у можливості утримувати напруженість у контрольованих межах.

Опір - це практична здатність офіцера оперативно-тактичної ланки управління протистояти тому, що обмежує свободу поведінки, свободу вибору, свободу управлінської діяльності як у процесі ухвалення окремих рішень, так і при виборі способів військово-професійної діяльності в цілому. Важливою стороною опірності $\epsilon$ особистісна, військово-професійна й управлінська самодостатність в аспекті свободи від певної залежності хімічної, інтеракційної, акцентованої односпрямованої поведінкової активності у процесі ухвалення управлінських рішень. Отже, опірність - це здатність офіцера протистояти тому, що обмежує свободу поведінки, свободу вибору i щодо окремих рішень, i щодо вибору способів військовопрофесійної діяльності в цілому.

Наукова новизна полягає у тому, що вперше обгрунтовано зміст емоційно-вольової стійкості майбутніх професіоналів військового управління. 
Висновки та перспективи подальших досліджень. У процесі наукового дослідження було 3'ясовано важливість емоційно-вольової стійкості військовослужбовців у військовій професійній діяльності. Аналіз наукових $\mathrm{i}$ літературних джерел показав, що успішність виконання поставлених завдань, особливо в екстремальних ситуаціях, суттєво залежить від емоційно-вольової стійкості. Узагальнення та систематизація отриманих даних дає можливість сформувати необхідні вимоги до розвитку емоційновольової стійкості майбутніх професіоналів військового управління та на основі цього спрогнозувати зміст їх емоційно-вольової стійкості. Перспективи подальших наукових досліджень - розроблення моделі емоційно-вольової стійкості майбутніх професіоналів військового управління.

\section{ЛІТЕРАТУРА}

1. Дзвоник Г. П. Роль емоційної стійкості в професійному самоздійсненні фахівця. Актуальні проблеми психології. Інститут психології імені Г.С. Костюка НАПН України, 2016. - Том. V. - C 24-29.

2. Зінченко С. В. Психологічна підготовка майбутніх фахівців пожежно-рятувальної служби до діяльності в екстремальних умовах: особистісний аспект /Зінченко С. В., Веселівський Р. Б. // Проблеми цивільного захисту населення:матеріали I Всеукраїнської заочної науково-практичної конференції, присвяченої180-річчю Національного педагогічного університету імені М.П. Драгоманова. - К. - С. 50-52.

3. Кокун О. М. Оптимізація адаптаційних можливостей людини у психофізіологічному забезпеченні діяльності: автореф. дис. д-ра психол. наук : спец. 19.00.02 "Психофізіологія" / О. М. Кокун. - К., 2004. - 31 с.

4. Косолапов О. М. Роль екстремальних умов службової діяльності рятувальників у виникненні негативних психічних станів / О. М. Косолапов // Проблеми екстремальної та кризової психології : зб. наук. праць. - Харків : УЦЗУ, 2010. - Вип. 7. - С. 218-227.

5. Петрикей О. О. Формування професійного саморозвитку майбутніх соціальних педагогів у процесі педагогічної практики / О. О. Петрикей // Вісник Глухівського національного педагогічного університету імені Олександра Довженка : зб. наук. праць. 2012. - Вип. 20 - С. 247-252.

6. Пилипенко К. В. Емоційна стійкість як професійно важлива якість майбутнього психолога-практика / К. В. Пилипенко // Практична психологія в системі вищої освіти: теорія, результати досліджень, технології : колективна монографія / ред. проф. Н. І. Пов'якель. - К. : НПУ імені М. П. Драгоманова, 2009. - С. 137-147.

7. Потапчук Є. М. Психологічна робота у Прикордонних військах України / Є. М. Потапчук // Морально-психологічне забезпечення службової діяльності Прикордонних військ України : підручник ; за заг. ред. Максименка С. Д., Олексієнка Б. М. Хмельницький : Вид-во НАПВУ, 2001. - С. 124-173.

8. Смирнов Б. А. Психология деятельности в экстремальных ситуациях / Б. А. Смирнов, Е. В. Долгополова.- Х. : Изд-во Гуманитарный Центр, 2007. - 292 с.

9. Розов В. И. Психология экстремальных ситуаций: адаптивность к стрессу и психологическое обеспечение : [научно-практ. пособие] / В. И. Розов. - К. : КНТ; СаммитКнига, 2012. -480 с.

10. Ягупов В. В. Кто должен быть результатом профессиональной подготовки будущих специалистов в системе высшего профессионального образования: личность, специалист, личность специалиста / В. В. Ягупов // Вісник Житомирського державного університету імені Івана Франка : науковий журнал. Педагогічні науки / [гол. ред. П.Ю. Саух, відп. ред. Н.А. Сейко]. - Житомир: Вид-во Євенюк О.О., 2017. - С. 297-302. 


\section{REFERENCES}

1. Zvonok, G. (2016). Rol emotsiynoyi stiykosti v profesiynomu samozdiysnenni fakhivtsya. Aktualni problemy psykholohiyi [The role of emotional stability in the professional self-realization of a specialist. Actual problems of psychology]. Instytut psykholohiyi imeni H.S. Kostyuka NAPN Ukrayiny, p. 24-29 (in Ukrainian).

2. Zinchenko, S. Psykholohichna pidhotovka maybutnikh fakhivtsiv pozhezhnoryatuvalnoyi sluzhby do diyalnosti $\mathrm{v}$ ekstremalnykh umovakh: osobystisnyy aspekt [Psychological training of future specialists of fire and rescue service to work in extreme conditions: personality aspect]. Problemy tsyvilnoho zakhystu naselennya: materialy Vseukrayinskoyi pozasudovoyi naukovo-praktychnoyi konferentsiyi, prysvyachenoyi 180richchyu Natsional $\square$ noho pedahohichnoho universytetu im. M.P. Drahomanova, p. 50-52 (in Ukrainian).

3. Kokun, O. (2004). Optymizasiya adatapsiinukh mozhluvostei ludyny u psikhofiziolohichnomu zabespechenni dayalnosti [Optimization of adaptive possibilities of a person in psychophysiological maintenance of activity]. Abstract of the doctor of psychological sciences(in Ukrainian).

4. Kosolapov, O. (2010). Rol ekstrimalnykh umov sluzhbovoi diyalnosti ryatuvalnykiv u vyneknenni negatyvnykh psykhichnykh staniv [The role of extreme conditions of service activity of rescuers in the emergence of negative mental states]. Problems of extreme and crisis psychology, 7, p. 218-227 (in Ukrainian).

5. Petrykey, O. (2012). Formuvannya profesiinogo samorozvutky maibutnikh sosialnykh pedagogiv u prosesi pedagogichnoi praktyky [Formation of Professional Self-Development of Future Social Teachers in the Process of Pedagogical Practice]. Bulletin of the Glukhov National Pedagogical University named after Alexander Dovzhenko, 20, p. 247-252(in Ukrainian).

6. Pylypenko, K. (2009). Emotsiyna stiykist yak profesiyno vazhlyva yakist maybutnoho psykholoha-praktyka [Emotional stability as a professionally important quality of the future psychologist-practice]. Praktychna psykholohiya v systemi vyshchoyi osvity: teoriya, rezultaty doslidzhen, tekhnolohiyi: kolektyvna monohrafiya. NPU imeni M. P. Drahomanova, p. 137147(in Ukrainian).

7. Potapchuk, Y. (2001). Psikholohichna robota u prykordonnykh viiskah Ukrainy [Psychological work in the Border Guards of Ukraine]. Moral and psychological support of the official activity of the border troops of Ukraine: a textbook, p. 124-173 (in Ukrainian).

8. Smirnov, B. (2007). Psikhologiya diyatelnosti v ekstrimalnykh sytuasii [Psychology of activity in extreme situations] (in Ukrainian).

9. Rozov, V. (2012). Psikhologiya ekstrimalnykh sytuasii: adaptivnost $\mathrm{k}$ stresu i psikholohicheskoe obespechenie [Psychology of extreme situations: adaptability to stress and psychological support] (in Ukrainian).

10. Yahupov, V. (2017) Kto dolzhen byt rezultatom professyonalnoy podhotovky budushchykh spetsyalystov $\mathrm{v}$ systeme vyssheho professyonalnoho obrazovanyya: lychnost, spetsyalyst, lychnost spetsyalysta [Who should be the result of professional training of future specialists in the system of higher professional education: personality, specialist, personality of a specialist]. Visnyk Zhytomyrskoho derzhavnoho universytetu imeni Ivana Franka: naukovyy zhurnal. Pedahohichni nauky, p. 297-302 (in Ukrainian).

\section{PЕЗЮМЕ}

Сергей Костив,

Национальный университет обороны Украины имени Ивана Черняховского

В данном исследовании теоретически обосновано эмоционально-волевую устойчивость военнослужащих, проведен анализ, обобщено и систематизировано информачию по обозначенной проблеме, полученную из научных и литературных 
источников. Использован метод прогнозирования для обоснования содержания эмоиионально-волевой устойчивости по развитию ее в будущих профессионалов военного управления. Научная новизна заключается в том, что впервые обосновано содержание эмочионально-волевой устойчивости будущих профессионалов военного управления. Проверка разработанной модели содержания эмочионально-волевой устойчивости будущих профессионалов военного управления в учебном процессе будет способствовать перспективе дальнейтих научных исследований.

Ключевые слова: эмоционально-волевая устойчивость; психологическая устойчивость; стресс-факторы; экстремальные условия; психические состояния; профессиональная деятельность военнослужащего.

\title{
SUMMARY
}

\author{
National Defence University of Ukraine \\ named after Ivan Cherniakhovskyi
}

\section{Emotional and volitional stability of future military professionals}

Introduction. Conducting modern combat operations requires military experts to possess mental stability, confidence in their actions and physical endurance. The problem of their emotional and volitional stability is of particular importance, and implies the speed of action and adequate behavior in a variety of complex and controversial situations, for example, in the ATO zone. Under these conditions, their insufficient development of emotional and volitional stability leads to false decisions, and in extreme cases - to panic, inadequate implementation of tasks or refusal to perform them.

The purpose of this study is to substantiate the content of the emotional and volitional stability of future professionals of military management and, based on the results obtained, to research and define the emotional and volitional resistance of future military management professionals.

Methods. A comprehensive scientific analysis has been done. The information obtained from scientific and literary sources has been generalized and systematized. The assumption method has been used to substantiate the content of the emotional and volitional stability of future military management professionals.

As a result of the analysis of scientific and literary sources, the value of emotional and volitional stability of military personnel and its components in their military professional activities have been determined. The emotional and volitional stability of future professionals of military management has been defined and the content of emotional and volitional stability of future professionals of military management has been substantiated.

Originality. The content of emotional and volitional stability of future professionals of military management has been substantiated for the first time.

Conclusion. The analysis of scientific and literary sources has shown that the success of the tasks performed, and especially in extreme situations, depends considerably on the development of the emotional and volitional stability of the military. Summarizing and systematizing the obtained data made it possible to predict the necessary requirements for the development of emotional and volitional stability of future professionals of military management.

The verification of the developed model of the content of emotional and volitional stability of future professionals of military management in the educational process will contribute to the prospect of further research.

Key words: emotional and volitional stability; psychological stability; stress factors; extreme conditions; mental states; professional activity of a serviceman. 